\title{
Screening Analyses of Pinosylvin Stilbenes, Resin Acids and Lignans in Norwegian Conifers
}

\author{
Hanne Hovelstad ${ }^{1}$, Ingebjorg Leirset ${ }^{1}$, Karin Oyaas ${ }^{1, \dagger}$ and Anne Fiksdahl ${ }^{2, *}$ \\ ${ }^{1}$ Paper and Fibre Institute (PFI), Høgskoleringen 6B, NO-7491 Trondheim, Norway. \\ 2 Department of Chemistry, Norwegian University of Science and Technology, NTNU, NO-7491 \\ Trondheim, Norway. \\ $\dagger$ Current address: Gaia Lab AS, NO-7228 Kvaal, Norway. \\ * Author to whom correspondence should be addressed; E-mail: $\underline{\text { Anne.Fiksdahl@ chem.ntnu.no }}$
}

Received: 6 January 2006; in revised form: 23 January / Accepted: 24 January 2006 / Published: 31 January 2006

\begin{abstract}
The content and distribution of stilbenes and resin acids in Scots pine (Pinus sylvestris) and spruce (Picea abies), sampled in central Norway, have been examined. The contents of pinosylvin stilbenes in pine heartwood/living knots were $0.2-2 / 2-8 \%$ $(w / w)$. No stilbenes could be detected in spruce (Picea abies). The resin acid contents of pine sapwood/heartwood and knots were 1-4 and 5-10\% $(\mathrm{w} / \mathrm{w})$, respectively. Minor amounts of resin acids $(<0.2 /<0.04 \% \mathrm{w} / \mathrm{w})$ were identified in spruce wood/knots. The lignan content in knots of Norwegian spruce was $6.5 \%(\mathrm{w} / \mathrm{w})$. Diastereomerically pure hydroxymatairesinol (HMR, $84 \%$ of total lignans) was readily isolated from this source since only minor quantities $(2.6 \%$ of total lignans) of the allo-HMR diastereomer was detected. Insignificant amounts of lignans were present in the sapwood. Lignans could not be detected in the sapwood or knots of Norwegian sallow (Salix caprea), birch (Betula pendula) or juniper (Juniperus communis).
\end{abstract}

Keywords: Betula pendula, hydroxymatairesinol, Juniperus communis, lignans, Norwegian wood samples, Picea abies, pinosylvins, Pinus sylvestris, resin acids, Salix caprea, stilbenes 


\section{Introduction}

\section{Stilbenes}

The content and distribution of pinosylvin and methyl ether derivatives in Scots pines (Pinus sylvestris) was reported some time ago [1] and the antiseptic action of these compounds towards wood-destroying fungi was investigated [2,3]. Pinosylvin and its monomethyl ether PMME (Scheme 1) appear to exhibit fungicidal activities towards wood-destroying fungi. The chemistry of wood durability and decay was studied and it was concluded that the resistance to decay by Scots pine is due to pinosylvins [4]. It was also shown [5] that both mechanical damage to the bark of the red pine $P$. resinosa as well as fungal penetration of sapwood caused the formation of pinosylvins while undamaged sapwood did not contain these compounds.

Subsequently there has been renewed interest in this area and increased attention has been paid to pinosylvins and their efficacy stopping fungal growth to make trees resistant towards fungal attack [69]. The formation of pinosylvin and its monomethyl ether has been reported to also be stress-induced by ozone treatment $[10,11]$ and additionally the compounds show antibacterial effects. It has been suggested that knotwood extracts from Pinus species could have a potential for use as natural biocides in papermaking [12]. Biochemical studies have demonstrated the formation and accumulation of pinosylvins as inhibitory substances by inoculation of fungus to pine species [13]. A cDNA encoding a pinosylvin-3-O-methyltransferase of Pinus sylvestris has been cloned and characterized. The enzyme catalyzes the conversion of pinosylvin to the monomethyl ether that plays a role in the resistance of the plant to stress including ozone and infection. It has been suggested that the enzyme therefore may be used to increase disease resistance in other plants [10,14]. The pinosylvin-3-O-methyltransferase gene of $P$. sylvestris, which catalyzes the methylation of pinosylvin, has been cloned and induced in the needles of trees exposed to ozone or fungus [15]. Large variations were found between individual trees; caused by a strong genetic control but also by environmental factors [16].

A report on the concentration of pinosylvins and resin acids in brown-rot resistant and susceptible juvenile heartwood of Scots pine (Pinus sylvestris) concludes that the concentration of total phenolics was higher in the decay-resistant heartwood than in the decay-susceptible heartwood [17]. Recently a solid study on the concentration of phenolics in brown-rot decay resistant and susceptible Scots pine heartwood discussed the contribution of stilbenes to the differences in the decay rate of natural wood substrate. The results showed that the stilbenes alone do not explain the variation in decay rate [18].

Another recent detailed study of Scots pine knots and stemwood detected large amounts of phenolic stilbenes, 1-7\% (w/w) in the knots, while the stemwood contained less than $1 \%(\mathrm{w} / \mathrm{w})$ [19]. The trees were collected in northern and southern Finland. Because of the large amounts of pinosylvins in pine, it has been suggested that other important species like spruce (Picea abies) should be analysed for its potential pinosylvin content [19].

\section{Lignans and resin acids}

Resin acids and lignans are also of interest due to their biological activity [20]. Their composition, distribution and roles were discussed quite early [21]. Lignans $(0.4-3 \% \mathrm{w} / \mathrm{w})$ have been reported in 
pine knots, while no detectable amounts were found in the stemwood. As for resin acids, the knots contained large amounts $(4.5-30 \% \mathrm{w} / \mathrm{w})$ and the stemwood minor amounts [19].

Lignans are found in large amounts $(6-24 \% \mathrm{w} / \mathrm{w})$, in Finnish spruce knots; with hydroxymatairesinol (HMR, Scheme 1) comprising $65-85 \%$ of these lignans. HMR has three chiral centers and occurs as two natural diastereomers. The major diasteromer has been proven to be the $7 S, 8 R, 8^{\prime} R$ isomer, while the minor isomer, allo-hydroxymatairesinol, has the $7 R, 8 R, 8^{\prime} R$ configuration [22]. In recent years hydroxymatairesinol has been used as a chiral source in the synthesis of derivatives with bioactive effects [22-28]. Sapwood tissue contains negligible amount of lignans. In general, only minor amounts of resin acids $(<2 /<0.5 \% \mathrm{w} / \mathrm{w}$ in stemwood/knots) have been detected in spruce samples [29-33]. No lignans have been found in Salic caprea [34] and minor amounts of lignan glycosides have been isolated from the inner bark of Betula pendula [35]. A lignan has been isolated from Juniperus communis berries. However, the wood has not been analysed [36].

Based on the present knowledge, mainly from trees sampled in Finland, and due to potential differences caused by geographical location, we wanted to undertake a screening analysis of stilbenes and resin acids in Norwegian conifers. We wanted to analyse the content and distribution of stilbenes in Scots pine (Pinus sylvestris) and spruce (Picea abies) sampled in central Norway. Because of the extraordinarily high content of lignans in Finnish spruce knots (Picea abies, 6-24 \% w/w) and the presence of lignans in the knots of Finnish pine (Pinus sylvestris, $<3 \% \mathrm{w} / \mathrm{w}$ ), we also wanted to analyse the lignan content in the sapwood and knots of central-Norwegian spruce (Picea abies) and in the hardwoods of sallow (Salix caprea), birch (Betula pendula) and juniper (Juniperus communis).

Scheme 1. Chemical structures of the identified stilbenes, resin acids and lignans.

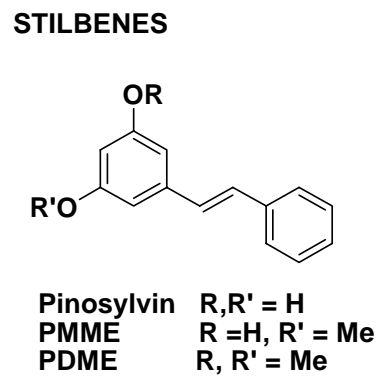

LIGNANS

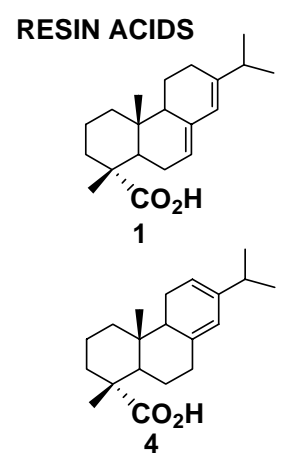

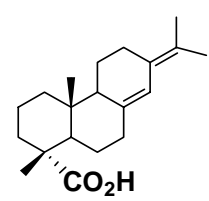

2

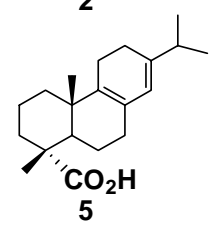

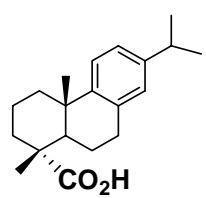

3

1 abietic acid

2 neoabietic acid

3 dehydroabietic acid

4 levopimaric acid

5 palustric acid

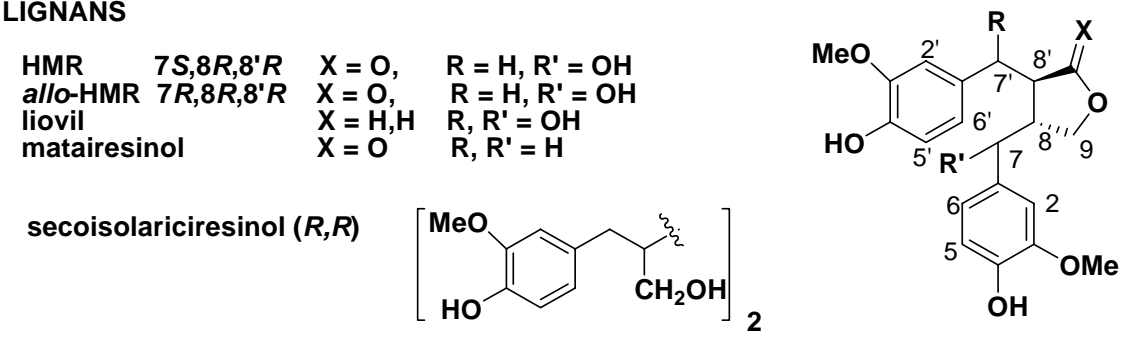




\section{Results and Discussion}

\section{Stilbenes}

The content and distribution of stilbenes in Scots pine (Pinus sylvestris) and spruce (Picea abies), both sampled in mid-Norway, have been examined, see Table 1 and Figure 1. Since quite large in-treeand between-tree variations have been reported in previous extensive studies [19], we limited our analyses to two pine trees of different ages (87 and 34 years) to examine whether the content and distribution of pinosylvins in these Norwegian trees were within the previously reported ranges for Finnish pine.

Table 1. Stilbene analyses of Norwegian pine and spruce (see Figure 1); content (\%, $\mathrm{w} / \mathrm{w})$ and distribution $(\% \text { of total })^{\mathrm{a}}$.

\begin{tabular}{|c|c|c|c|c|c|}
\hline & & Heartwood & St.dev.(\%) & Knots & St.dev.(\%) \\
\hline \multicolumn{6}{|l|}{ PINE 87 years } \\
\hline \multirow[t]{3}{*}{$0 \mathrm{~m}$} & Pinosylvin & 0.980 & $0.110(11)$ & n.s. & \\
\hline & PMME & 0.940 & $0.110(11)$ & n.s. & \\
\hline & PDME & 0.110 & $0.009(9)$ & n.s. & \\
\hline IN TOTAL & & 2.030 & $0.229(11)$ & & \\
\hline \multirow[t]{3}{*}{$3.5 \mathrm{~m}$} & Pinosylvin & 0.750 & $0.072(10)$ & 0.910 & $0.066(7)$ \\
\hline & PMME & 0.870 & $0.095(11)$ & 1.100 & 0.033 \\
\hline & PDME & 0.090 & $0.010(10)$ & 0.057 & $0.006(10)$ \\
\hline IN TOTAL & & 1.710 & $0.177(10)$ & 2.067 & $0.105(5)$ \\
\hline \multirow[t]{3}{*}{$5 \mathrm{~m}$} & Pinosylvin & 0.610 & $0.029(5)$ & 3.500 & $0.690(20)$ \\
\hline & PMME & 0.570 & $0.002(2)$ & 4.800 & 0.280 \\
\hline & PDME & 0.095 & $0.014(2)$ & 0.055 & $0.007(12)$ \\
\hline IN TOTAL & & 1.275 & $0.045(4)$ & 8.355 & $0.977(12)$ \\
\hline \multicolumn{6}{|l|}{ PINE 34 years } \\
\hline \multirow[t]{3}{*}{$0 \mathrm{~m}$} & Pinosylvin & 0.150 & $0.008(5)$ & n.s. & \\
\hline & PMME & 0.120 & $0.0065(6)$ & n.s. & \\
\hline & PDME & 0.006 & $0.0003(3)$ & n.s. & \\
\hline IN TOTAL & & 0.276 & $0.0148(5)$ & & \\
\hline \multirow[t]{3}{*}{$3.5 \mathrm{~m}$} & Pinosylvin & 0.120 & $0.013(11)$ & 1.200 & $0.230(19)$ \\
\hline & PMME & 0.100 & $0.007(7)$ & 1.300 & $0.029(2)$ \\
\hline & PDME & 0.012 & $0.001(8)$ & 0.054 & $0.002(3)$ \\
\hline IN TOTAL & & 0.232 & $0.021(9)$ & 2.554 & $0.261(10)$ \\
\hline \multicolumn{6}{|c|}{ SPRUCE 27 years } \\
\hline $0 \mathrm{~m}$ & Pinosylvins & 0.000 & & n.s. & \\
\hline $3.5 \mathrm{~m}$ & Pinosylvins & 0.000 & & 0.000 & \\
\hline
\end{tabular}

PMME: Pinosylvin monomethyl ether, PDME; pinosylvin dimethyl ether;

${ }^{\text {a }}$ All results are based on three parallel analyses; n.s. = no sample analysed 
Figure 1. Stilbene analyses of Norwegian pine and spruce; content $(\%, w / w)$ and distribution

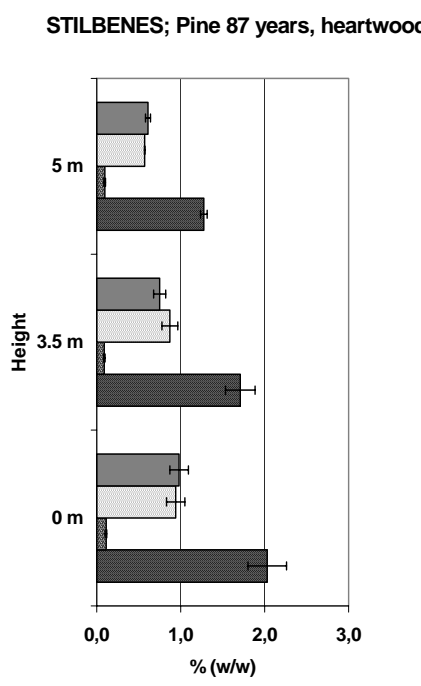

STILBENES; Pine 34 years, heartwood
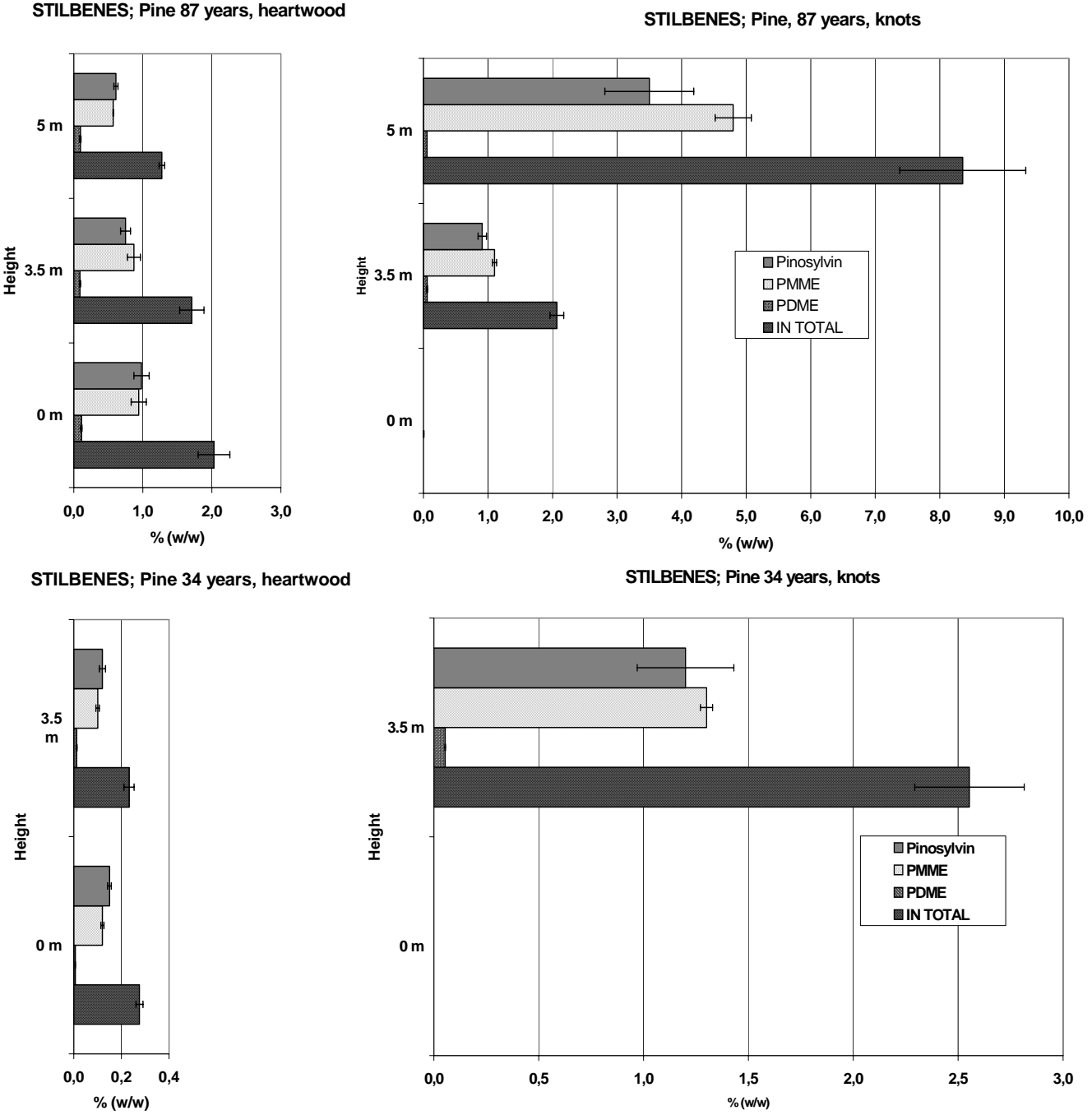

Samples were taken at different heights $(0,3.5$ and $5 \mathrm{~m})$. We found that the stilbene content in pine heartwood and wood from the living knots was on average $0.2-2 \%(\mathrm{w} / \mathrm{w})$ and $2-8 \%(\mathrm{w} / \mathrm{w})$. Due to the low number of samples analysed, no general conclusion can be drawn with respect to content and distribution related to height and age. The results are in accordance with data from pine sampled in Finland, which was $<1 \%$ and $1-7 \%(\mathrm{w} / \mathrm{w})$, respectively; living knots were in the higher range (approx. $4-7 \% \%$ ) $[18,19]$. Our results for the distribution of pinosylvin (P), pinosylvin monomethyl ether (PMME) and dimethyl ether (PDME) differs however from previous data. The PMME/P ratio has been reported to be 1.1-2.3 in heartwood and 1.8-4.4 in knots. In our samples pinosylvin monomethyl ether (PMME) was definitely less abundant since we observed a PMME/P ratio of 1.1-1.4 in the knots and $<1$ in the heartwood. Based on the reports that the pinosylvin 3-O-methyltransferase enzyme of Pinus sylvestris catalyzes the conversion of pinosylvin $(\mathrm{P})$ to the monomethyl ether (PMME) induced by stress [10,14,15], a high concentration of pinosylvin monomethylether (PMME) relative to pinosylvin $(\mathrm{P})$ may be an indication of high stress levels of the trees. It follows from this that the central Norwegian pine samples may represent trees of lower stress levels. In contrast to the pine samples, no detectable amounts of stilbenes could be found in the heartwood or knots of the tested 27 year old spruce (Picea abies) sample. Spruce has not previously been analysed for stilbenes. 


\section{Lignans and resin acids}

Correspondingly, the resin acid content of sapwood/heartwood in Scots pine (Pinus sylvestris), sampled in central Norway, was 0.3-1.1 \% / 1.4-4.4 \% (w/w), while the content in living knots was 5$10 \%(\mathrm{w} / \mathrm{w})$, see Table 2 and Figure 2.

Table 2. Resin acid analyses of Norwegian pine and spruce (see Figure 2); content (\%, $\mathrm{w} / \mathrm{w})$ and distribution ( $\%$ of total $)^{\mathrm{a}}$.

\begin{tabular}{|c|c|c|c|c|c|c|c|}
\hline \multirow{2}{*}{\multicolumn{2}{|c|}{ PINE 87 years }} & \multirow[t]{2}{*}{ Sapwood } & \multirow[t]{2}{*}{ St.dev.(\%) } & \multirow[t]{2}{*}{ Heartwood } & \multirow[t]{2}{*}{ St.dev. $(\%)$} & \multirow[t]{2}{*}{ Knots } & \multirow[t]{2}{*}{ St.dev. (\%) } \\
\hline & & & & & & & \\
\hline \multirow[t]{5}{*}{$0 \mathrm{~m}$} & Neoabietic acid & 0.040 & $0.01(25)$ & 0.820 & $0.170(20)$ & n.s. & \\
\hline & Abietic acid & 0.033 & $0.01(30)$ & 1.400 & $0.147(10)$ & n.s. & \\
\hline & Dehydroab.+ & 0.150 & $0.04(23)$ & 1.600 & $0.570(35)$ & n.s. & \\
\hline & levopimaric acids (lp.a.) & & & & & & \\
\hline & Palustric acid & 0.048 & $0.01(25)$ & 0.590 & $0.150(26)$ & n.s. & \\
\hline \multicolumn{2}{|c|}{ IN TOTAL } & 0.271 & $0.07(25)$ & 4.410 & $1.037(24)$ & & \\
\hline \multirow[t]{4}{*}{$3.5 \mathrm{~m}$} & Neoabietic acid & 0.075 & $0.005(7)$ & 0.200 & $0.024(12)$ & 2.300 & $0.11(5)$ \\
\hline & Abietic acid & 0.051 & $0.003(6)$ & 0.600 & $0.058(10)$ & 3.900 & $0.30(8)$ \\
\hline & Dehydroab + lp.a. & 0.260 & $0.020(8)$ & 0.390 & $0.050(13)$ & 2.700 & $0.31(11)$ \\
\hline & Palustric acid & 0.083 & $0.007(8)$ & 0.170 & $0.030(18)$ & 1.700 & $0.12(7)$ \\
\hline \multicolumn{2}{|c|}{ IN TOTAL } & 0.469 & $0.035(7)$ & 1.360 & $0.162(12)$ & 10.600 & $0.84(8)$ \\
\hline \multirow[t]{4}{*}{$5 \mathrm{~m}$} & Neoabietic acid & 0.110 & $0.045(41)$ & 0.640 & $0.063(10)$ & 1.700 & $0.17(10)$ \\
\hline & Abietic acid & 0.071 & $0.016(22)$ & 1.200 & $0.071(6)$ & 2.100 & $0.36(17)$ \\
\hline & Dehydroab. + lp. a. & 0.400 & $0.087(22)$ & 1.200 & $0.067(6)$ & 1.100 & $0.13(12)$ \\
\hline & Palustric acid & 0.130 & $0.025(19)$ & 0.540 & $0.065(12)$ & 0.430 & $0.07(15)$ \\
\hline \multicolumn{2}{|c|}{ IN TOTAL } & 0.711 & $0.173(24)$ & 3.580 & $0.266(7)$ & 5.330 & $0.73(14)$ \\
\hline \multicolumn{8}{|c|}{ PINE 34 years } \\
\hline \multirow[t]{4}{*}{$0 \mathrm{~m}$} & Neoabietic acid & 0.190 & $0.028(15)$ & & & n.s. & \\
\hline & Abietic acid & 0.280 & $0.023(9)$ & & & n.s. & \\
\hline & Dehydroab. + lp.a. & 0.530 & $0.057(11)$ & & & n.s. & \\
\hline & Palustric acid & 0.160 & $0.018(11)$ & & & n.s. & \\
\hline \multicolumn{2}{|c|}{ IN TOTAL } & 1.160 & $0.126(11)$ & & & & \\
\hline \multirow[t]{4}{*}{$3.5 \mathrm{~m}$} & Neoabietic acid & 0.130 & $0.068(5)$ & & & 1.900 & $0.10(5)$ \\
\hline & Abietic acid & 0.190 & $0.011(6)$ & & & 3.600 & $0.26(7)$ \\
\hline & Dehydroab. + lp.a. & 0.330 & $0.017(5)$ & & & 1.900 & $0.16(9)$ \\
\hline & Palustric acid & 0.120 & $0.009(8)$ & & & 1.000 & $0.18(18)$ \\
\hline \multicolumn{2}{|c|}{ IN TOTAL } & 0.770 & $0.044(6)$ & & & 8.400 & $0.70(8)$ \\
\hline \multicolumn{8}{|c|}{ SPRUCE 27 years } \\
\hline \multirow[t]{4}{*}{$0 \mathrm{~m}$} & Neoabietic acid & 0.011 & $0.0004(3)$ & & & n.s. & \\
\hline & Abietic acid & 0.018 & $0.0005(3)$ & & & n.s. & \\
\hline & Dehydroab. + lp.a. & 0.095 & $0.0057(6)$ & & & n.s. & \\
\hline & Palustric acid & 0.046 & $0.0018(4)$ & & & n.s. & \\
\hline \multicolumn{2}{|c|}{ IN TOTAL } & 0.170 & $0.0084(5)$ & & & & \\
\hline
\end{tabular}


Table 2. Cont.

\begin{tabular}{lllcll}
\hline $3.5 \mathrm{~m} \quad$ Neoabietic acid & 0.006 & $0.001(16)$ & 0 & \\
& Abietic acid & 0.016 & $0.0004(2)$ & 0 & \\
Dehydroab. + lp.a. & 0.110 & $0.014(13)$ & 0.021 & $0.01(22)$ \\
& Palustric acid & 0.045 & $0.008(18)$ & 0.014 & $0.00(15)$ \\
IN TOTAL & $\mathbf{0 . 1 7 7}$ & $0.023(13)$ & $\mathbf{0 . 0 3 5}$ & $0.01(22)$ \\
\hline
\end{tabular}

${ }^{\mathrm{a}}$ All results are based on three parallel analyses; n.s.; no sample analysed

Figure 2. Resin acid analyses of Norwegian pine and spruce; content $(\%, w / w)$ and distribution.

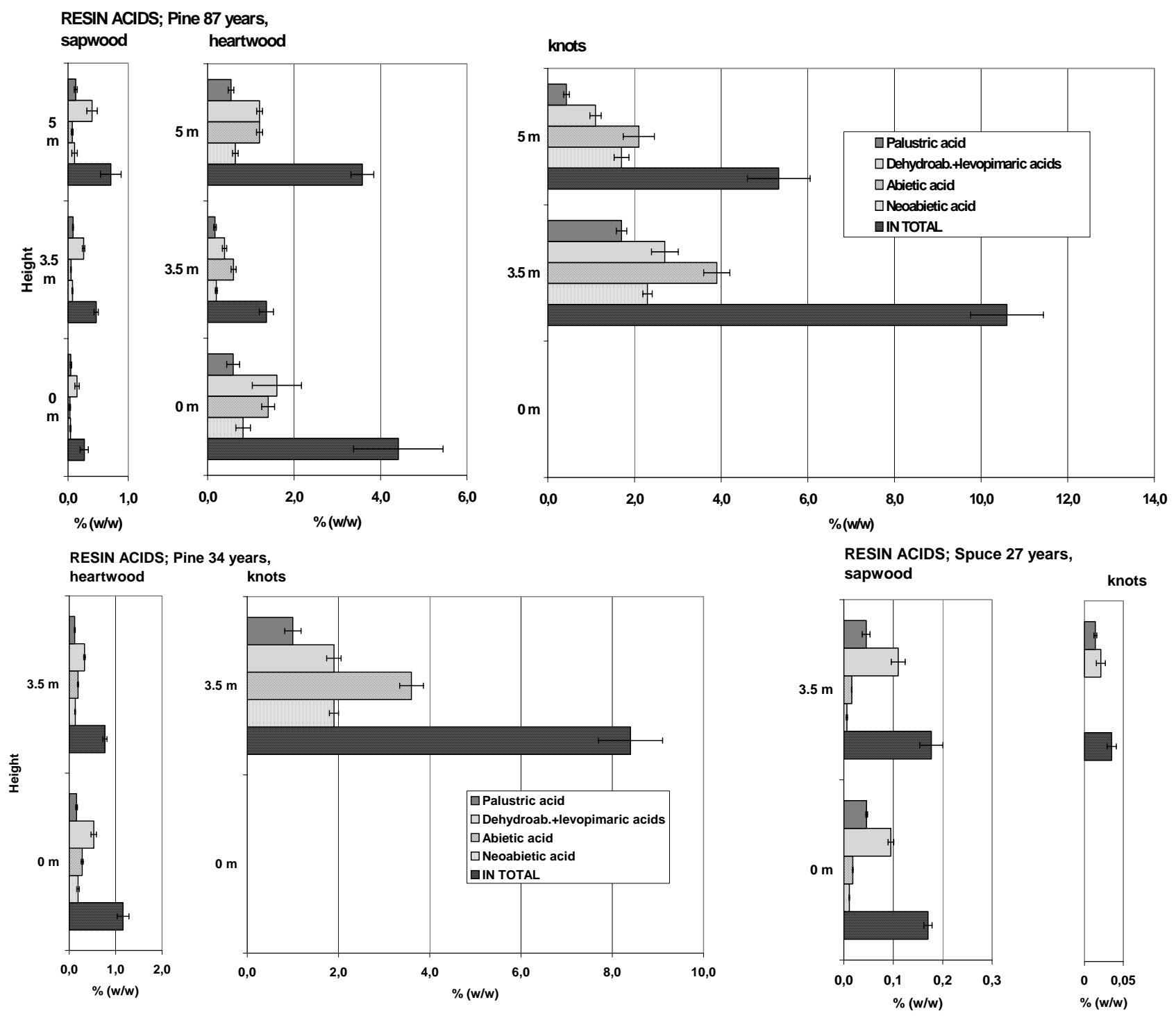

The content in knots was 1.5-8 fold compared to the content in heartwood and thus indicating a lower ratio than reported in Finland (10-30 fold) [19]. Abietic acid was the most abundant resin acid in all knot samples. The content and distribution of resin acids in Norwegian pine are in the same range as corresponding data from trees sampled in Finland. The Finnish pine knots contained large amounts, 4.5-30\% $(\mathrm{w} / \mathrm{w})$, and the stemwood 1-3.5 \% (w/w) of resin acids. Lower concentrations of resin acids in spruce (Picea abies) wood $(<0.2 \% \mathrm{w} / \mathrm{w})$ and knots $(<0.04 \% \mathrm{w} / \mathrm{w})$ were identified in our samples 
compared to Finnish spruce samples $(<0.2$ and $<0.04 \% \mathrm{w} / \mathrm{w}$, respectively) [33]. The lignan content in living knots of the Norwegian spruce samples (Picea abies) was approx. $6.5 \%(\mathrm{w} / \mathrm{w})$, while only trace amounts were detected in the sapwood (see Table 3). Hydroxymatairesinol (HMR) was identified as the major lignan, amounting to $85 \%$ of the total amount present. These results are in accordance with previous reports from Finland. The content of lignans present in Finnish spruce knots has been reported to be $6-24 \%(\mathrm{w} / \mathrm{w}$ ) [33] with HMR comprising $65-85 \%$ of the lignans. No detectable amounts of lignans was found in the stemwood.

Table 3. Lignan analyses of Norwegian spruce, sallow, birch and juniper; content (\%, $\mathrm{w} / \mathrm{w})$ and distribution (\% of total) ${ }^{\mathrm{a}}$.

\begin{tabular}{clll}
\hline Norwegian spruce (Picea abies) & Knots & $\%$ & Sapwood \\
\hline Hydroxymatairesinol & 5.50 & 84 & - \\
Allo-hydroxymatairesinol & 0.17 & 2.6 & - \\
Liovil & 0.22 & 3.4 & - \\
Other lignans (incl. secoisolariciresinol, & 0.65 & 10.0 & - \\
matairesinol) & & & \\
IN TOTAL (st. dev. 2.34\%) & $\mathbf{6 . 5 4}$ & 100.0 & trace amounts \\
\hline Norwegian sallow (Salix caprea) & n.d. & & n.d. \\
Norwegian birch (Betula pendula) & n.d. & & n.d. \\
Norwegian juniper (Juniperus communis) & n.d. & & n.d. \\
\hline
\end{tabular}

${ }^{\text {a }}$ All results are based on three parallel analyses; n.d. = not detectable

HMR exists as two naturally occurring diastereomers, which has been isolated as an approx. 1:3 mixture [30]. The two isomers, having the absolute configuration $7 S, 8 R, 8^{\prime} R$ (HMR, major isomer) and $7 R, 8 R, 8^{\prime} R$ (allo-HMR, minor isomer) [22,26], can be separated by $\mathrm{GC}$ and distinguished based on their ${ }^{1} \mathrm{H}-\mathrm{NMR}$ assignments,. However, based on GC-MS, ${ }^{1} \mathrm{H}$ - and ${ }^{13} \mathrm{C}-\mathrm{NMR}$, we could only observe minor amounts $(2.6 \%$ of the total amount lignans) of the allo-hydroxymatairesinol diastereomer, giving a ratio of the two isomers of 1:32. Minor amounts of matairesinol, secoisolariciresinol and liovin $(<0.22 \% \mathrm{w} / \mathrm{w}$ of each, less than $3 \%$ of total amount of lignans) were identified. HMR, diastereomerically pure by ${ }^{1} \mathrm{H}$ - and ${ }^{13} \mathrm{C}-\mathrm{NMR}$, was readily isolated from the crude extract and characterised. Our data indicate that the present spruce sample represents a purer and better source for isolation of hydroxymatairesinol as a chiral substrate for the preparation of fine chemicals.

No detectable amounts of lignans could be identified neither in the sapwood nor the knots of Norwegian sallow (Salix caprea), birch (Betula pendula) or juniper (Juniperus communis). Lignans have not been identified in sallow [34], birch or juniper previously. The major component identified by GC-MS in the sallow extract was catechin; $2.1 / 0.8 \%(\mathrm{w} / \mathrm{w})$ in knots and sapwood, respectively. The major components in juniper extracts were $\Delta^{9}$-dehydroferruginol/ferruginol (ratio 4:3), present in approx. $1.0 \%(\mathrm{w} / \mathrm{w}$, knots) and $0.5 \%(\mathrm{w} / \mathrm{w}$, sapwood), respectively.

\section{Conclusions}

The content and distribution of stilbenes and resin acids in Scots pine (Pinus sylvestris) and spruce (Picea abies) sampled in central Norway have been examined. The stilbene contents in pine heartwood 
and knotwood were 0.2-2 \% (w/w) and 2-8 \% (w/w), respectively. Pinosylvin (P) was more abundant in our Norwegian samples, as we observed a distinctly lower PMME/P ratio compared to previous Finnish reports. No stilbenes could be detected in spruce. The resin acid content of pine sapwood/heartwood was 1-4 \% (w/w), while the content in knots was 5-10\% (w/w). Only minor amounts of resin acids were identified in spruce wood $(<0.2 \% \mathrm{w} / \mathrm{w})$ and knots $(<0.04 \% \mathrm{w} / \mathrm{w})$. Correspondingly, the lignan content in knots of Norwegian spruce was approx. $6.5 \%(\mathrm{w} / \mathrm{w})$, while only trace amounts were detected in sapwood. The major lignan, diastereomerically pure hydroxymatairesinol (HMR, $84 \%$ of total lignans) was readily isolated from the extract. In contrast to previous reports, only minor amounts ( $2.6 \%$ of total lignans) of the isomeric allo-HMR were detected. No detectable amounts of lignans were found in the sapwood or knots of Norwegian sallow (Salix caprea), birch (Betula pendula) or juniper (Juniperus communis). Our data from Norwegian spruce and pine are in accordance with previous data from trees sampled in Finland since, in general, no significant differences were observed between the stilbene, resin acid or lignan contents of trees sampled in Norway and Finland. The absence of stilbenes in spruce (knots and heartwood) and of lignans in sapwood has not been reported previously.

\section{Experimental}

\section{Materials}

Trees were collected from about 70 meters above sea level at Melhus in central Norway. Two Scots pines (Pinus sylvestris), 34 and 87 years old, respectively, and one spruce (Picea abies), 27 years old, were sampled in February. For lignan studies Norwegian spruce (Picea abies), sallow (Salix caprea), birch (Betula pendula) and juniper (Juniperus communis) were sampled in September. The samples were frozen immediately upon cutting. Prior to analysis samples were cut into 1-2 cm cross sectional slices. Wood knots, sapwood and heartwood were isolated, cut into small pieces by hand and freeze dried before grinding into particles to form "wood meal" (<30 mesh, Wiley mill). All results are given as weight percent of compound relative to weight of freeze-dried wood $(\% \mathrm{w} / \mathrm{w})$.

\section{Methods}

Stilbenes and resin acids: Extraction and GC analysis. Wood meal (0.1-0.5 g) was extracted (Soxhlet) with acetone for 6 hours. Betulinol (Sigma, $>98 \%, 2 \mathrm{mg} / \mathrm{mL}$ ) and heptadecanoic acid $(2 \mathrm{mg} / \mathrm{mL}$ ) in an acetone/pyridine mixture (70:30) were added as internal standards. The extract was dried $\left(\mathrm{Na}_{2} \mathrm{SO}_{4}\right.$, $0.5 \mathrm{hrs}$.), filtered (GF/A filter, Whatman) and further dried to complete dryness $\left(35^{\circ} \mathrm{C}, \mathrm{N}_{2}\right.$ gas). The dry extracts were dissolved in the injection standard (heptadecane in a 30:70 mixture of dry cyclohexane and pyridine, $5.0 \mathrm{mg} / \mathrm{mL}$ ) prior to silylation (Trisil). If further dilution was necessary, samples were diluted with dry cyclohexane. Samples were centrifuged prior to GC analysis. The sample extracts $(1 \mu \mathrm{L})$ were analyzed by GC/MS on a crosslinked methylsiloxane column (HP-1, $25 \mathrm{~m}$ x $0.20 \mathrm{~mm} \times 0.11 \mu \mathrm{m})$ using $\mathrm{He}(0.8 \mathrm{~mL} / \mathrm{min})$ as a carrier gas. Identification of the pinosylvins and resin acids was based on authentic reference standards of the resin acids (abietic acid, neoabietic acid, dehydroabietic acid, levopimaric acid, palustric acid) and pinosylvin. 
Lignans: Extraction. Wood meal (0.1-0.5 g) was extracted (Soxhlet) with acetone/water (9:1) for 3 hours. Betulinol (Sigma, > $98 \%, 2 \mathrm{mg} / \mathrm{mL}$ ) in ethanol was added as internal standard. The acetone was evaporated and the samples were freeze dried, dissolved in dry pyridine (2-3 $\mathrm{mL})$ and silylated (3 : 1.2 mixture of bis(trimethyl)trifluoracetamide and trimethylchlorosilane, $70^{\circ} \mathrm{C}, 2 \mathrm{hrs}$.). The samples were dried to complete dryness $\left(35^{\circ} \mathrm{C}, \mathrm{N}_{2}\right.$ gas) and dissolved in the injection standard (heptadecane, Sigma $>98 \%$, in dry cyclohexane, $0.5 \mathrm{mg} / \mathrm{mL})$. This solution $(40 \mu \mathrm{L})$ was transferred to a silylated GC-vial (treated with Cylon-CT for 1 minute) with dry cyclohexane. GC analysis was performed as described above. A correction factor of 1.2 was used for calculation of lignan concentrations [37]. Identification of the lignans HMR, allo-HMR, liovil, matairesinol and secoisolariciresinol was based on GC-MS comparison with authentic reference compounds.

NMR, IR and HRMS analysis of hydroxymatairesinol (HMR). Wood meal was extracted as described above without the addition of internal standard. The extract was dried. ${ }^{1} \mathrm{H} /{ }^{13} \mathrm{C}-\mathrm{NMR}$ spectra were recorded in $d_{6}$-acetone on a Bruker Avance DPX $400 \mathrm{MHz}$ spectrometer operating at 400 and 100 $\mathrm{MHz}$, respectively, HRMS on a Finnigan MAT $95 \mathrm{XL}(\mathrm{EI}-70 \mathrm{eV})$ instrument and IR with a Nicolet 20SXC FT-IR spectrophotometer. IR (KBr) 3422s, 3050w, 2935w, 1750m, 1604w, 1516s, 1227s, 1032s cm ${ }^{-1}$; ${ }^{1} \mathrm{H}-\mathrm{NMR}: \delta 2.60$ (m, 1H, H-8), 2.93 (m, 2H, H-7',8'), 3.77 (s, 3H, $\mathrm{OCH}_{3}$ ), 3.80 (s, 3H, $\mathrm{OCH}_{3}$ ), 3.94 (dd, 1H, H-9), 4.00 (dd, 1H, H-9), 4.63 (dd, 1H, H-7), 6.56 (dd, J=8.0 and $1.8 \mathrm{~Hz}, 1 \mathrm{H}, \mathrm{H}-$ 6'), 6.68 (m, 2H, H-2,2'), 6.79 (m, 2H, H-5',6), 6.92 (d, J=8.0 Hz, 1H, H-5), 7.36 (br., 1H, OH), 7.50 (br., 1H, OH); ${ }^{13} \mathrm{C}-\mathrm{NMR}: \delta 35.5\left(\mathrm{C}-7^{\prime}\right), 43.9\left(\mathrm{C}-8^{\prime}\right), 46.1(\mathrm{C}-8), 56.1\left(\mathrm{OCH}_{3}\right), 56.2\left(\mathrm{OCH}_{3}\right), 69.1$, $(\mathrm{C}-$ 9), 74.7 (C-7), 110.4 (C-2), 114.1 (C-2'), 115.4/115.5 (C-5/5'), 119.6 (C-6), 123.3 (C-6'), 130.3 (C1'), 135.4 (C-1), 146.1 (C-4'), 146.8 (C-4), 148.1 (C-3'), 148.3 (C-3), 179.6 (C=O, C-9'); HRMS: calcd for $\mathrm{C}_{20} \mathrm{H}_{22} \mathrm{O}_{7} ; 374.13656$; observed 374.13598.

\section{References}

1. Erdtman, H.; Misiorny, A. Constituents of pine heartwood. XXXI. The content of pinosylvin phenols in Swedish pines. Svensk Papper. 1952, 55, 605-8.

2. Erdtman, H.; Rennerfelt, E. The pinosylvin-phenolic content of pine heartwood; its determination and its antiseptic action towards wood-destroying fungi. Svensk Papper. 1944, 47, 45-56.

3. Rennerfelt, E. Investigations on the toxicity to rot fungi of the phenolic components of pine heartwood. Medd. Skogsforsoksanst. 1944, 33, 331-64. Rennerfelt, E. Investigations on the toxicity to rot fungi of the phenolic components of pine heartwood. Rev. Appl. Mycol. 1944, 23, 465.

4. Anderson, A.; Richmond, B. The chemistry of wood durability and decay. Structure of fungicidal components in some cedars. Symposium on Phytochemistry, Proceedings Golden Jubilee Congress of the Univ. of Hong Kong, 1964, 101-16.

5. Jörgensen, E. The formation of pinosylvin and its monomethyl ether in the sapwood of Pinus resinosa. Can. J. Bot. 1961, 39, 1765-72.

6. Celimene, C. C.; Micales, J. A.; Ferge, L.; Young, R. A. Efficacy of pinosylvins against white-rot and brown-rot fungi. Holzforschung 1999, 53, 491-497. 
7. Bois, E.; Lieutier, F. Phenolic response of Scots pine clones to inoculation with Leptographium wingfieldii, a fungus associated with Tomicus piniperda. Plant Physiol.Biochem. 1997, 35, 819825 .

8. Bois, E.; Lieutier, F.; Yart, A. Bioassays on Leptographium wingfieldii, a bark beetle associated fungus, with phenolic compounds of Scots pine phloem. Eur. J. Plant Pathol. 1999, 105, 51-60.

9. Gref, R.; Hakansson, C.; Henningsson, B.; Hemming, J. Influence of wood extractives on brown and white rot decay in scots pine heart-, light- and sapwood. Mat. Organism. 2000, 33, 119-128.

10. Chiron, H.; Drouet, A.; Ernst, D.; Sandermann, H. Pinus ozone- and fungi-inducible pinosylvin-3O-methyltransferase gene PMT and use of promoter and/or gene to produce pathogen-resistant plants. WO 2001059139 (2001); [Chem. Abstr. 2001, 135, 176487].

11. Chiron, H.; Drouet, A.; Claudot, A. C.; Eckerskorn, C.; Trost, M.; Heller, W. E.; Sandermann Jr., $\mathrm{H}$. Molecular cloning and functional expression of a stress-induced multifunctional Omethyltransferase with pinosylvin methyltransferase activity from Scots pine (Pinus sylvestris L.). Plant Mol. Biol. 2002, 44, 733-45.

12. Lindberg, L. E.; Willför, S. M.; Holmbom, B. R. Antibacterial effects of knotwood extractives on paper mill bacteria. J. Ind. Microbiol. Biot. 2004, 31, 137-47.

13. Yamada, T.; S. Ito, S. Chemical defense responses of wilt-resistant pine species, Pinus strobus and P. taeda, against Bursaphelenchus xylophilus infection. Nippon Shoku. Byori Gak. 1999, 59, 66672.

14. Heller, W.; Sandermann, H.; Ernst, D.; Drouet, A.; Chiron, H. A. Pinosylvine-3-Omethyltransferase of Pinus sylvestris and the gene encoding it and their use in improving plant disease resistance. EP 979874 (2000); [Chem. Abstr. 2000, 132, 148490].

15. Amiour, N.; Jahier, J.; Tanguy, A. M.; Chiron, H.; Branlard, G. Effect of 1R(1A), 1R(1B) and 1R(1D) Substitution on Technological Value of Bread Wheat. J. Cereal Sci. 2002, 35, 149-160.

16. Fries, A.; Ericsson, T.; Gref, R. High heritability of wood extractives in Pinus sylvestris progeny tests. Can. J. Forest Res. 2000, 30, 1707-1713.

17. Harju, A. M.; Venäläinen, M.; Anttonen, S.; Viitanen, H.; Kainulainen, P.; Saranpää, P.; Vapaavuori, E. Chemical factors affecting the brown-rot decay resistance of Scots pine heartwood. Trees 2003, 17, 263-268.

18. Venäläinen, M.; Harju, A. M.; Saranpää, P.; Kainulainen, P.; Tiitta M.; Velling. P. The concentration of phenolics in brown-rot decay resistant and susceptible Scots pine heartwood. Wood Sci. Tech. 2004, 38, 109-118.

19. Willför S. M.; Hemming, J.; Reunanen, M.; Holmbom, B. Phenolic and lipophilic extractives in Scots pine knots and stemwood. Holzforschung 2003, 57, 359-372.

20. Willför, S. M.; Ahotupa, M. O.; Hemming, J. E.; Reunanen, M. H. T.; Eklund, P. C.; Sjöholm, R.; Eckerman, C.; Pohjamo, S. P.; Holmbom, B. R. Antioxidant activity of knotwood extractives and phenolic compounds of selected tree species. J. Agr. Food Chem. 2003, 51, 7600-7606.

21. Stanley, R. G. Extractives of wood, bark, and needles of the southern pines. A review. Forest Prod. J. 1969, 19, 50-6.

22. Eklund, P.; Sillanpää, R.; Sjöholm, R. Synthetic transformation of hydroxymatairesinol from Norway spruce (Picea abies) to 7-hydroxysecoisolariciresinol, (+)-lariciresinol and (+)cyclolariciresinol. J. Chem. Soc., Perkin Trans. 1 2002,, 1906-1910. 
23. Sjöholm, R.; Eklund, P.; Riska, A. Synthesis of derivatives from hydroxymatairesinol. WO 2003066557 (2003); [Chem. Abstr. 2003, 139, 179927].

24. Sjöholm, R.; Eklund, P.; Mikkola, J.-P. Method for the preparation of lariciresinol, cyclolariciresinol and secoisolariciresinol from hydroxymatairesinol. WO 2003059340 (2003); [Chem. Abstr. 2003, 139, 117269].

25. Sjöholm, R.; Eklund, P.; Mikkola, J.-P.; Lehtilae, R.; Södervall, M.; Kalapudas, A. Preparation of matairesinol from hydroxymatairesinol. WO 2003057209 (2003); [Chem. Abstr. 2003, 139, 117267].

26. Eklund, P. C.; Riska, A. I.; Sjöholm, R. E. Synthesis of R-(-)-Imperanene from the Natural Lignan Hydroxymatairesinol. J. Org. Chem. 2002, 67, 7544-7546.

27. Eklund, P.; Sjöholm, R. E. Oxidative transformation of the natural lignan hydroxymatairesinol with 2,3-dichloro-5,6-dicyano-1,4-benzoquinone Tetrahedron 2003, 59, 4515-4523.

28. Eklund, P.; Lindholm, A.; Mikkola, J.-P.; Smeds, A.; Lehtilae, R.; Sjöholm, R. Synthesis of (-)Matairesinol, (-)-Enterolactone, and (-)-Enterodiol from the Natural Lignan Hydroxymatairesinol. Org. Lett. 2003, 5, 491-493.

29. Buchert, J.; Mustranta, A.; Tamminen, T.; Spetz, P.; Holmbom, B. Modification of spruce lignans with. Holzforschung 2002, 56, 579-584.

30. Ekman, R. Distribution of lignans in Norway spruce. Acta Academiae Aboensis, Ser. B: Math. Phys. 1979.

31. Kimland, B.; Norin, T. Wood extractives of common spruce, Picea abies. Svensk Papper. 1972, 75, 403-9.

32. Leont'eva, V. G. New lignan compounds from firwood and sprucewood. Issled. Obl. Khim. Drev.,Tezisy Dokl., Konf. Molodykh Uch. 1978, 36-7.

33. Willför, S. M.; Hemming, J.; Reunanen, M.; Eckerman, C.; Holmbom, B. Lignans and lipophilic extractives in Norway spruce knots and stemwood. Holzforschung 2003, 57, 27-36.

34. Pohjamo, S. P.; Hemming, J. E.; Willför, S. M.; Reunanen, S. H. T.; Holmbom, B. R. Phenolic extractives in Salix caprea wood and knots. Phytochemistry 2003, 63, 165-9.

35. Smite, E.; Pan, H.; Lundgren, L. N. Lignan glycosides from inner bark of Betula pendula. Phytochemistry 1995, 40, 341-3.

36. Sakar, M. K.; Er, N.; Ercil, D.; Del Olmo, E.; San Feliciano, A. (-)-Desoxypodophyllotoxin and diterpenoids from Juniperus nana Willd. berries. Acta Pharm. Turc. 2002, 44, 213-219.

37. Willför, S. M. Water-soluble Polysaccharides and Phenolic Coumpounds in Norway Spruce and Scots Pine Stemwood and Knots. Dissertation Åbo Akademi, Finland; [Diss. Abstr. Int., C 2003, $64,413]$.

Sample availability: Contact the authors

(C) 2006 by MDPI (http://www.mdpi.org). Reproduction is permitted for noncommercial purposes. 